\title{
PUPILS' AND STUDENTS' PERCEPTIONS AND REPRESENTATIONS OF THE WOODEN CHURCHES IN MARAMUREŞ, ROMANIA
}

\author{
SORIN-ALIN KOSINSZKI \\ Babeş-Bolyai University, Faculty of Geography, Cluj-Napoca, Romania, \\ e-mail: kosinszki.sorin@gmail.com \\ MARIA ELIZA DULAMĂ \\ Babeş-Bolyai University, Faculty of Psychology and Sciences of Education, Cluj-Napoca, Romania, \\ e-mail: dulama@upcmail.ro
}

\section{GABRIELA OSACI-COSTACHE}

University of Bucharest, Faculty of Geography, Bucharest, Romania,

e-mail: gabrielaosaci68@yahoo.com

\author{
MARIA HOTEA \\ "Mircea Vulcănescu" Secondary School, Bârsana, Maramureş County, Romania, \\ e-mail: mhotea@yahoo.com
}

(Received: March 2013; in revised form: June 2013)

\begin{abstract}
The main objective of the research was to study the perceptions and representations of some pupils and students, living in Maramureş, of the wooden churches from Maramureş and their employment as tourist attractions. The specific objectives of this research were the following: conceiving, analysing and applying a research instrument for the perceptions and representations on the wooden churches from Maramureş and their employment as tourist attractions, the analysis and interpretation of the obtained results. The following research hypothesis was tested: pupils and students do not have very precise representations of the wooden churches in Maramureş and their employment as tourist attractions. After the questionnaire was applied and the results were analyzed, the working hypothesis was confirmed.
\end{abstract}

Keywords: UNESCO, tourist attraction, patrimony, the geography of tourism, historic monument. 


\section{SORIN-ALIN KOSINSZKI, MARIA ELIZA DULAMĂ, GABRIELA OSACI-COSTACHE, MARIA HOTEA}

\section{INTRODUCTION}

We have designed this research starting from the finding that pupils and students have difficulties and gaps in the perception and representation on the wooden churches in Maramureş, including those in their home localities, in the awareness of their importance, in preserving and their employment as tourist attractions. We underline that the territory of our research is that of the Historical Maramureş or the Land of Maramureş, from the administrative unit Maramureş County, Romania. This deficiency in perception and representation causes poor employment of the cultural tourism potential at a local and regional level. The essential question that we sought to answer was: "How do the $8^{\text {th }}$ grade pupils and also students from the specialization Geography of Tourism perceive and represent to themselves the old wooden churches in the local and regional horizon as well as their employment as tourist attractions?"

The main objective of our research was to study the perceptions and representations of some pupils and students, living in Maramureş, on the wooden churches in Maramureş and their employment as tourist attractions. The specific objectives of this research were the following:

1) conceiving and analysing a research instrument for the perceptions and representations on the wooden churches in Maramureş and their employment as tourist attractions;

2) applying the research instrument for the perceptions and representations on the wooden churches in Maramureş, the analysis and interpretation of the obtained results.

The research hypothesis was the following: pupils and students do not have very precise representations on the wooden churches in Maramureş and their employment as tourist attractions.

\section{THEORETICAL SUBSTANTIATION}

In the geographical, historical and ethnographical literature, we identified several studies dedicated to the analysis of the traditional spiritual and material heritage in the Land of Maramureş. We mentioned a few of the most recent. The monograph "Maramureş a Living Museum in the Centre of Europe" (Cristea, Dăncuş, 2000) stands out, presenting the Historical Maramureş, which includes a chapter on the characteristic architecture of churches and wooden gates with the spiritual meanings of the religious buildings. We found out complex information concerning the wooden churches in the "Tourist Guide Book of the Land of Maramureş" (Ivanciuc, 2006). Valuable information and images on each old wooden church in the 
entire Maramureş County was provided to us by the study "Wooden Churches in Maramureş" (Man, 2007).

Regarding the belief systems and the value of education, we mention the empirical research conducted by De Roux and Du Preez (2006). A study on the perceptions of residents concerning religious tourism and its socioeconomic impact was conducted by Terzidou, Stylidis and Szivas (2008), "Perception of Religious Tourism and Its Socio-Economic Impacts on the Island of Tinos". We did not identify studies on pupils' and students' perceptions and representations on the wooden churches in the Land of Maramureş, and this is the reason why the present paper fills a gap in the literature.

\section{METHOD}

In order to achieve the research objectives and to test the hypothesis, we designed a questionnaire, applied it, eventually analysing and interpreting the data. This pilot research has empirical and descriptive character, and the results cannot be generalized.

\section{Place and time of research}

Our research took place at the "Mircea Vulcănescu" Secondary School in Bârsana locality, and at the Babeș-Bolyai University, Faculty of Geography, the Academic Branch in Sighetu Marmaţiei, both in Maramureş County, during 2013.

\section{Participants}

The research involved 57 subjects residing in Maramureș. The first group consisted of $258^{\text {th }}$ grade pupils, from the above-mentioned secondary school, and the second group of 32 second year students, from the specialization Geography of Tourism. We did not select a representative sample of the pupils' population in Maramureş, but we involved in the research all the pupils from an $8^{\text {th }}$ grade, in order to have a larger number of participants. In addition, for the same reason, we included in the survey all the students in the second year from the mentioned specialization.

The pupils formed a heterogeneous group considering gender and the level of proficiency in Geography, but homogeneous in age (13-14 years) and relatively homogenous in religion (23 were Orthodox and 2 were Greek Catholic). Students formed a heterogeneous group considering age (19-24 years old), gender, level of proficiency in Geography and relatively homogenous in religion (26 were Orthodox, 2 were Greek Catholic and 4 were Neoprotestant). These pupils and students accepted their answers to the questionnaire to be used in research provided anonymity and 
SORIN-ALIN KOSINSZKI, MARIA ELIZA DULAMĂ, GABRIELA OSACI-COSTACHE, MARIA HOTEA

confidentiality is respected.

\section{Procedure}

The questionnaire (Appendix 1), printed on paper, was administered directly to pupils and students. They responded immediately to the questionnaire items. The questionnaire is original. It assesses knowledge about the wooden churches in Maramureș and participants' opinions about their employment as tourist attractions. The questionnaire included 22 items requiring selection or finding closed, semi-closed and open answers. In the structure of the questionnaire, we used objective items (dual choice items, multiple-choice items, pair type items) and short response, semi objective items. Through the questionnaire, we obtained quantitative and qualitative data.

The collection, processing and representation of data

The data for the research were collected through the questionnaire by researchers. The entire research team was involved in the activity of processing the data. For the processing of data, we used the statistical and mathematical method, and for the graphical representation, we used the Microsoft Excel application.

\section{RESULTS}

At the first item - What do you understand by the Land of Maramureş? - all the surveyed 25 pupils and 32 students answered correctly and circled answer $b$. The Historical Maramureş.

At item number 2 - What are the religions/confessions present in the Land of Maramureş? - at Orthodoxy all the surveyed pupils and students answered correctly, at Catholicism 24 pupils answered correctly (96\%) and all the students (32), at Protestantism only two pupils and 11 students answered correctly, and at Judaism only one student answered correctly. At Islam and Taoism there were no answers neither from pupils, nor from students, which is a correct response (Fig. 1). 
PUPILS' AND STUDENTS' PERCEPTIONS AND REPRESENTATIONS ...

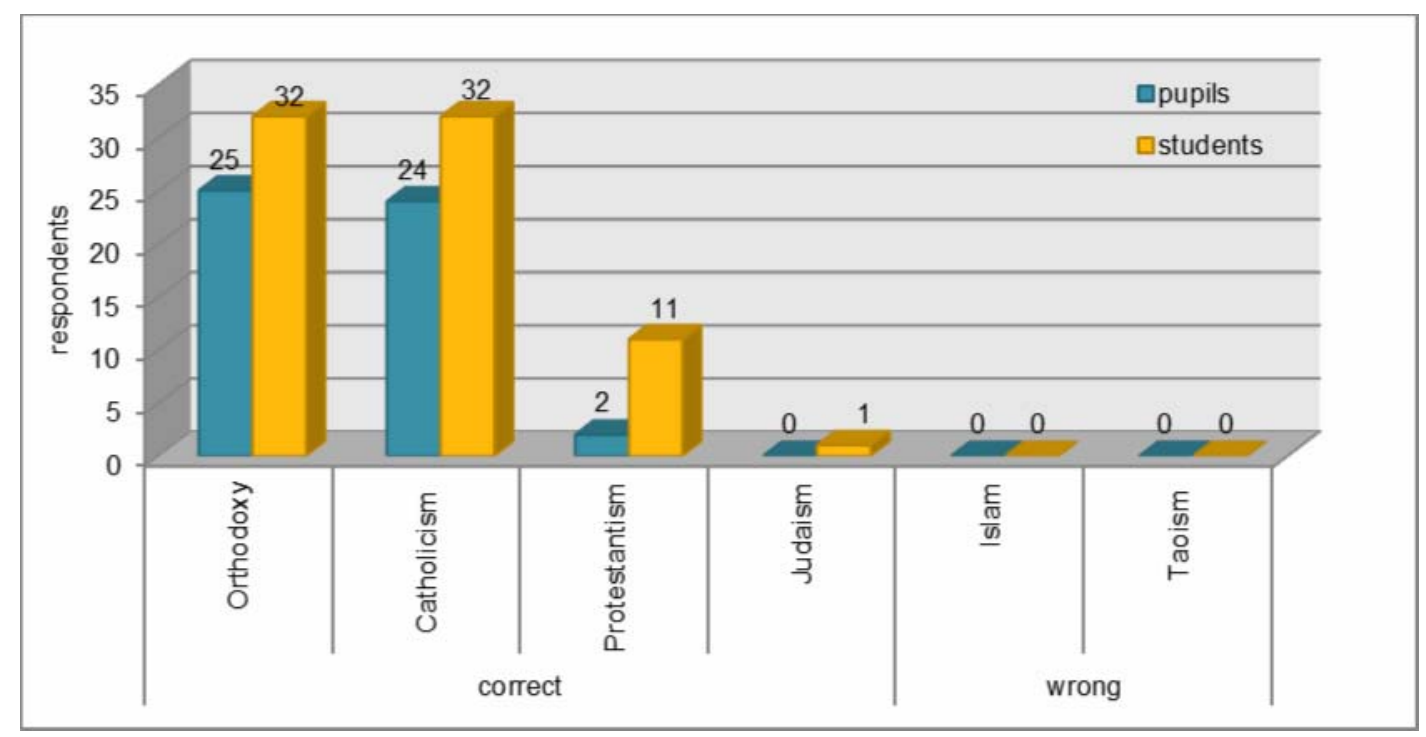

Fig. 1. Representations concerning religions/confessions present in the Land of Maramureş

At item number 3 - What types of places of worship exist in the Land of Maramureş? - both pupils and students knew that in the Land of Maramureş there were no mosques and pagodas (Fig. 2). Regarding the places of worship that really existed there, all students indicated correctly the wooden churches and, to a lesser extent ( $68 \%$ of pupils and $56.25 \%$ of students), the stone churches. The existence of houses of prayer was recognised by only two pupils and nine students, while the existence of synagogues was totally unknown to pupils, but not to students (Fig. 2).

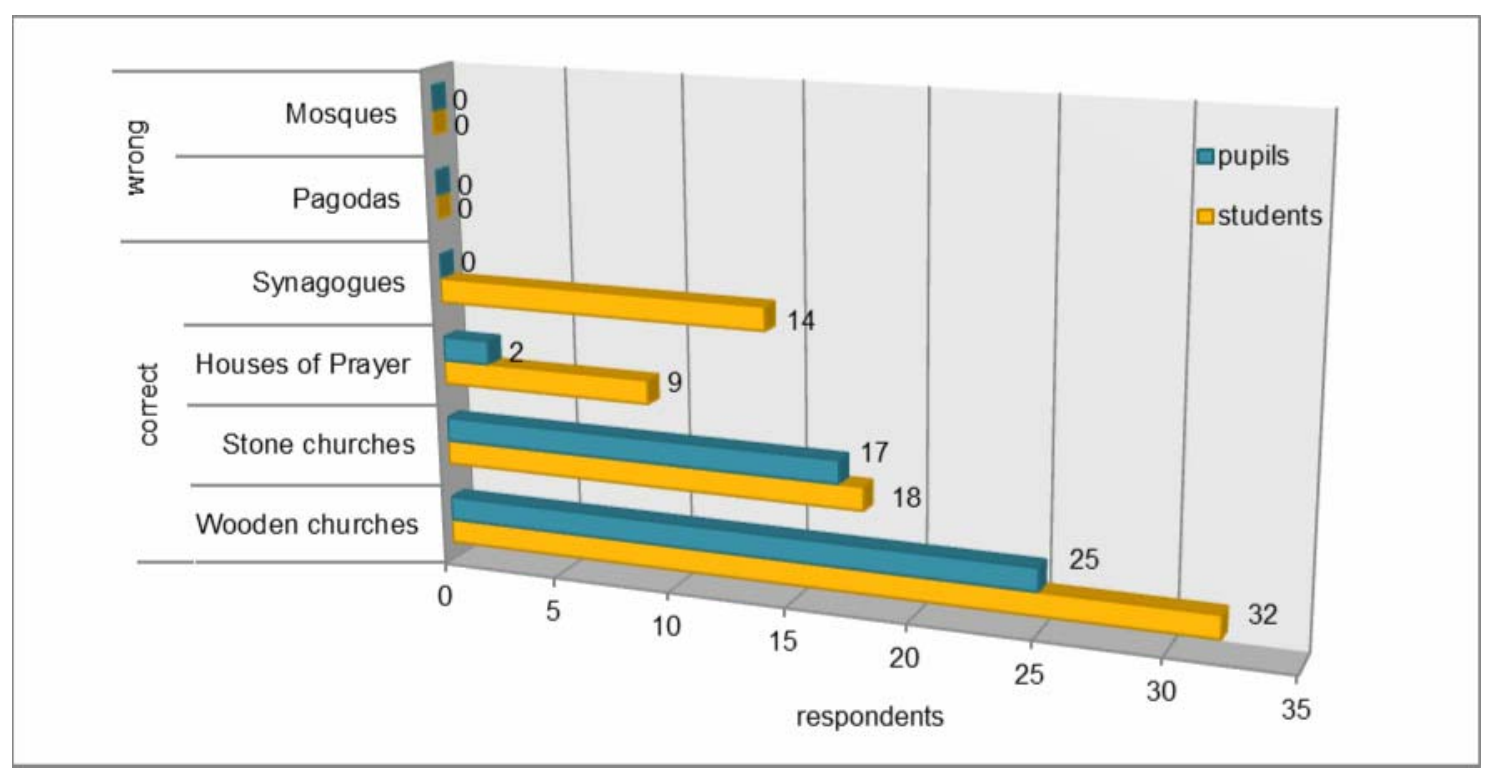

Fig. 2. Representations concerning types of places of worship present in the Land of Maramureş 


\section{SORIN-ALIN KOSINSZKI, MARIA ELIZA DULAMĂ, GABRIELA OSACI-COSTACHE, MARIA HOTEA}

At item number 4, the surveyed pupils and students had to join with a line the types of places of worship in column $B$ with the religions/confessions in column $\mathrm{A}$. We considered as correct answers the following combinations: Orthodoxy - Wooden Churches, Catholicism Stone Churches, Protestantism - Houses of prayer, Islam - Mosques, Judaism - Synagogues, Taoism - Pagodas. At the first two associations, pupils scored the fewest correct answers, two, and the most wrong answers, 23. Students, instead, scored at the first two associations, the most correct answers, 31 and 25. At the following four associations, all students registered only correct answers, and more than half of the students gave correct answers (Fig. 3).

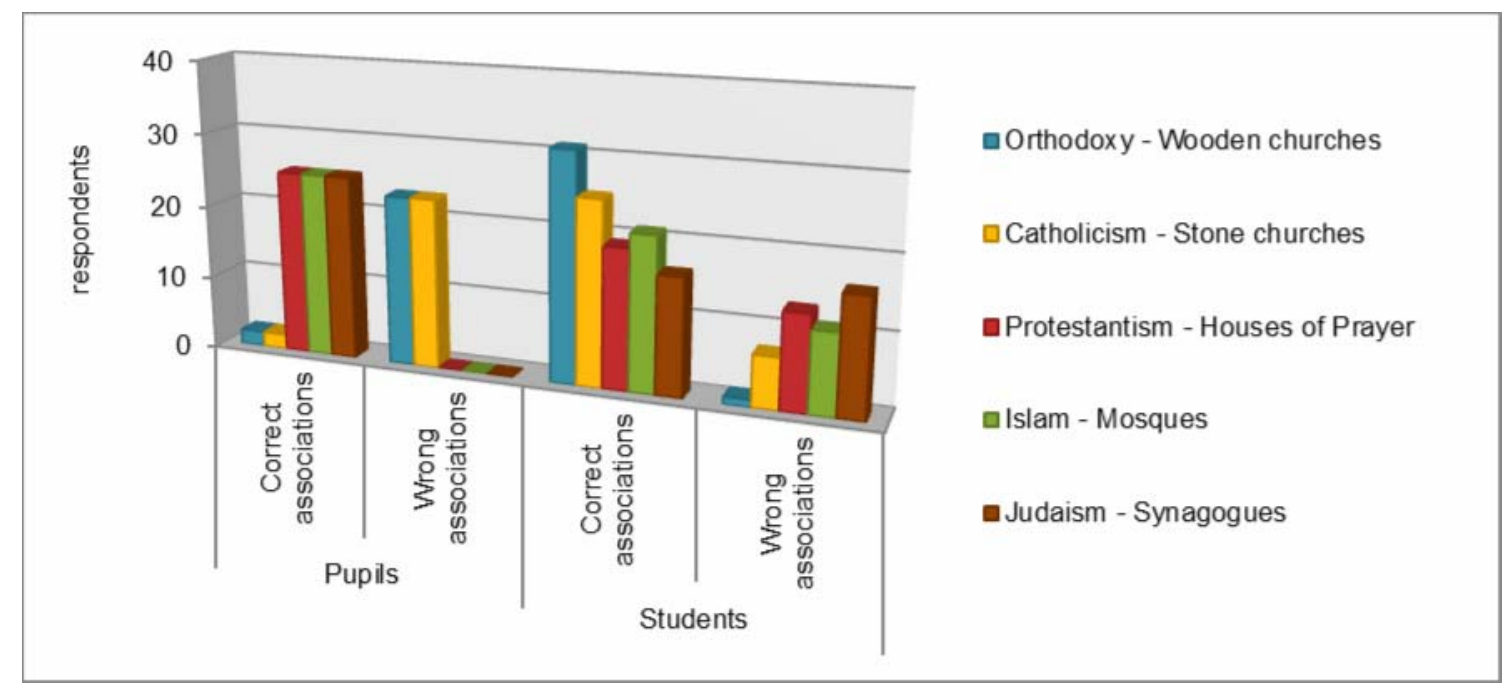

Fig. 3. Representations concerning the association religion - places of worship

At item number 5 - How many old churches/with monument value do you think there are in the Land of Maramureş? - only three students answered correctly (over 25 old churches/with monument value), in the Land of Maramureş being 42 churches of this kind (Fig. 4). 
PUPILS' AND STUDENTS' PERCEPTIONS AND REPRESENTATIONS ...

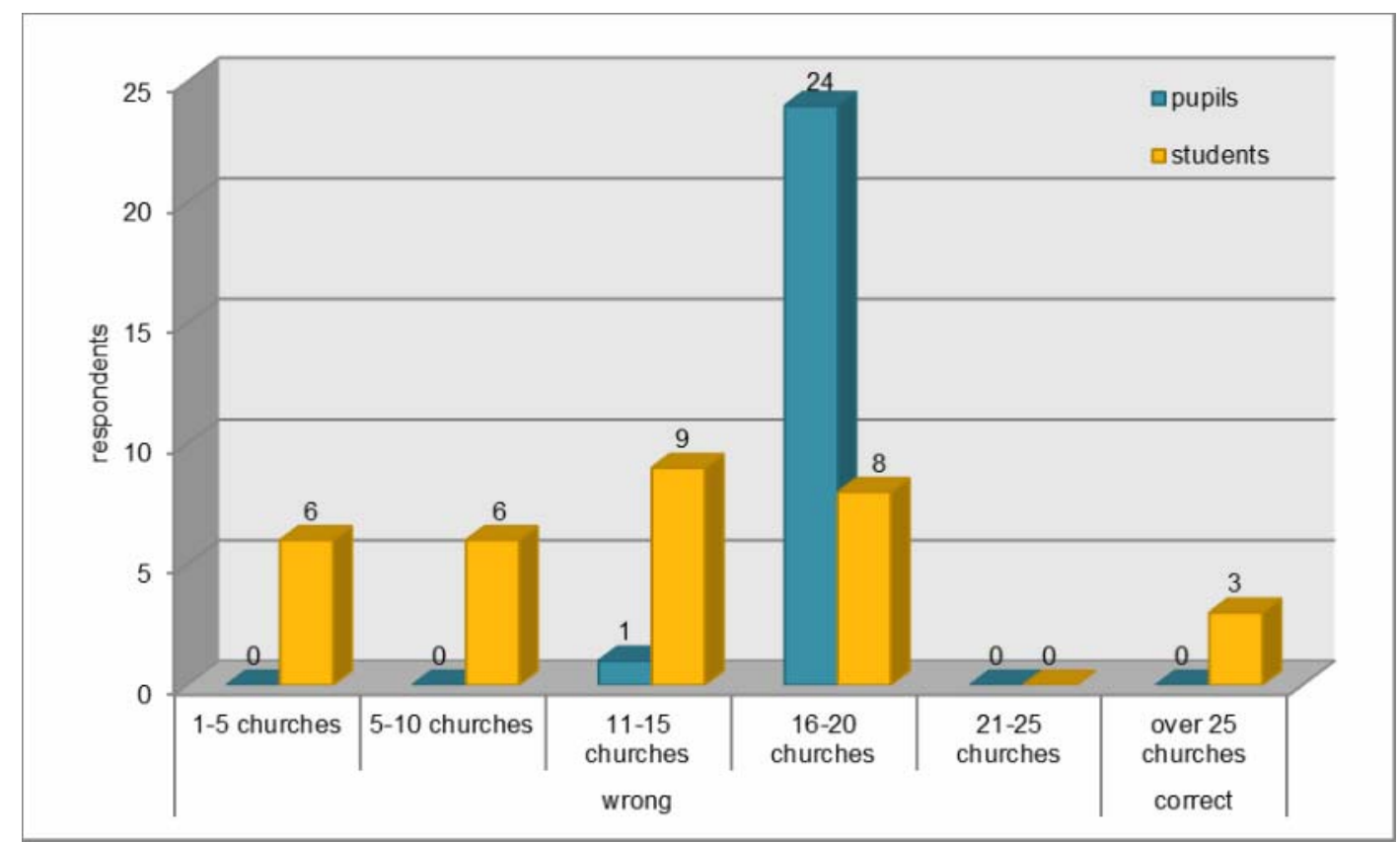

Fig. 4. Representations concerning the number of old churches/with monument value in the Land of Maramureş

At item number 6 - How many of these churches are built of stone? only 13 students answered correctly (between 5 and 10 old churches/with monument value built of stone), in the Land of Maramureş being 10 such churches (Fig. 5).

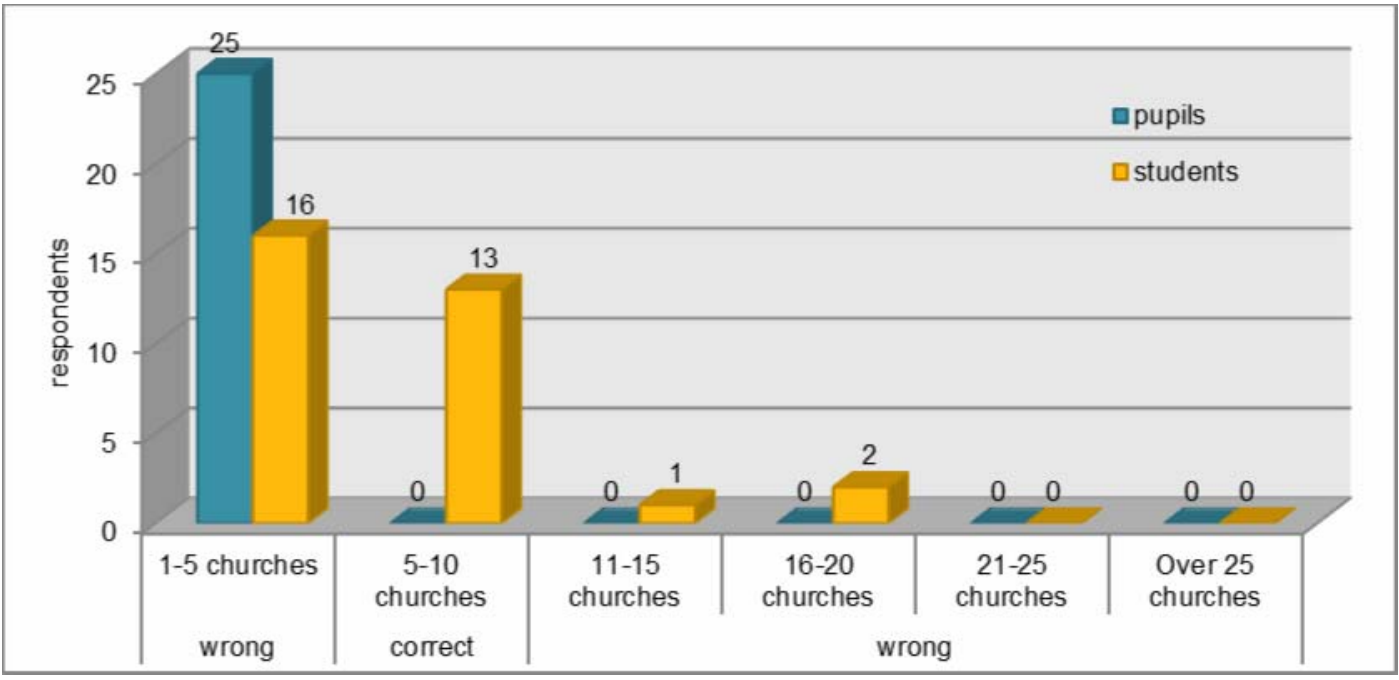

Fig. 5. Representations concerning the number of stone built old churches/with monument value in the Land of Maramureş

At item number 7 - How many of these churches are built of wood? only two students answered correctly (over 25 old churches/with monument value built from wood), in the Land of Maramureş being 32 such churches (Fig. 6). 

MARIA HOTEA

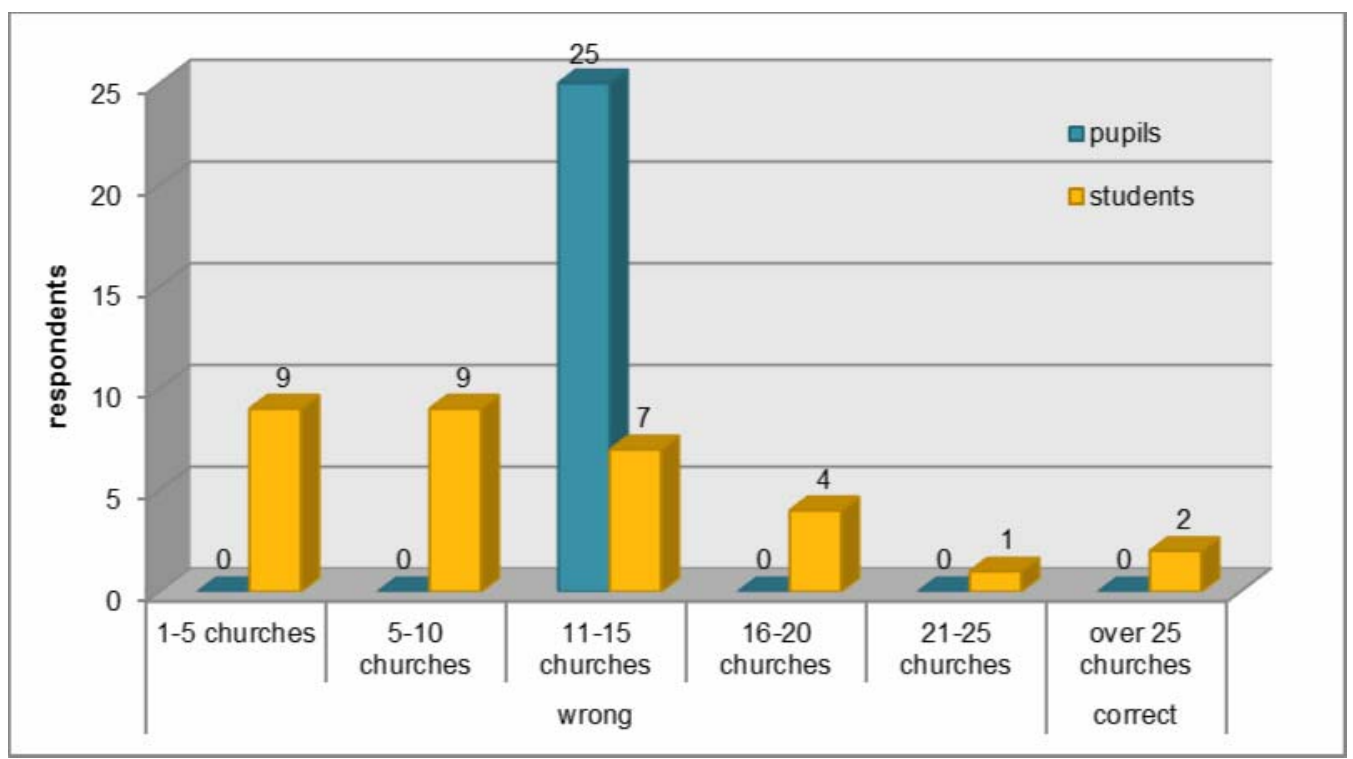

Fig. 6. Representations concerning the number of old churches/with monument value built of wood in the Land of Maramureş

At item number 8 - Which old churches/with monument value in the Land of Maramureş do you think are more valuable: the wood or the stone ones? Please motivated choice - all pupils answered that the wooden churches are the most valuable. They gave the following reasons: they were older or very old (20); they were very old and were more valuable (2); they were old and there were wooden carvings (1); they were more valuable (1); one pupil did not motivate his choice (Fig. 7).

31 students answered that the wooden churches were more valuable, while one student did not answer at all (Fig. 7). They gave the following reasons: because wood was the less resistant material. The fact that it lasted gave value (1); wood was a representative element for the Land of Maramureş (1); they were old and they resisted until nowadays (1); due to style and their age (1); due to their aspect and legends (1); because they appeared first and had a traditional aspect; they were characteristic of the Land of Maramureş; they had a unique style, different sizes, originality (1); they had a thing or element that distinguished them (age; authenticity of architectural style) (1); they had historical value; The church in Săpânţa had the highest tower in the world (1); it presented architecture specific to this area and they were distinguished by their age and historical evidence (manuscripts); they characterized our area (specific to) (1); they had the authenticity of architectural style (1); due to age; authenticity of architectural style (1); specific architecture (1); they lasted centuries and represented the traditional part for the art of wood carving, of wood - they were more numerous and more valuable; they symbolised the Land of Maramureş; they were representative of the Land of Maramureş; unique architectural style; Maramureş is well known for wood art, Ieud, Săpânţa, Bârsana, Deseşti, Hărniceşti (because they were in the UNESCO heritage); they kept the heat; wood was the material most commonly used in building 
PUPILS' AND STUDENTS' PERCEPTIONS AND REPRESENTATIONS ...

traditionally; the church from Ieud was the oldest and it was included in the UNESCO heritage.

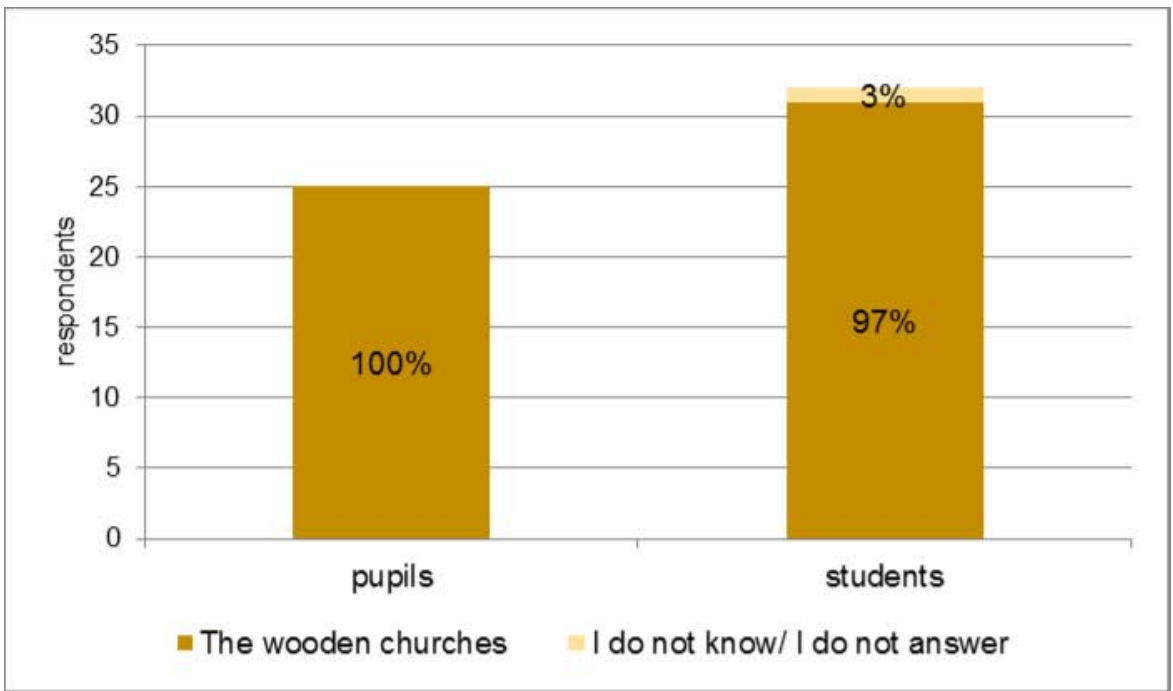

Fig. 7. Representations concerning the value of wooden/stone churches in the Land of Maramureş

At item number 9 - What are the attributes that give value to old wooden or stone monument churches in general? - more than half of the pupils and almost all students answered that these attributes were: age, but also authenticity of architectural style. Students placed a greater emphasis on history but also on mural icons, unlike pupils, who scored very few responses at these variants (Fig. 8).

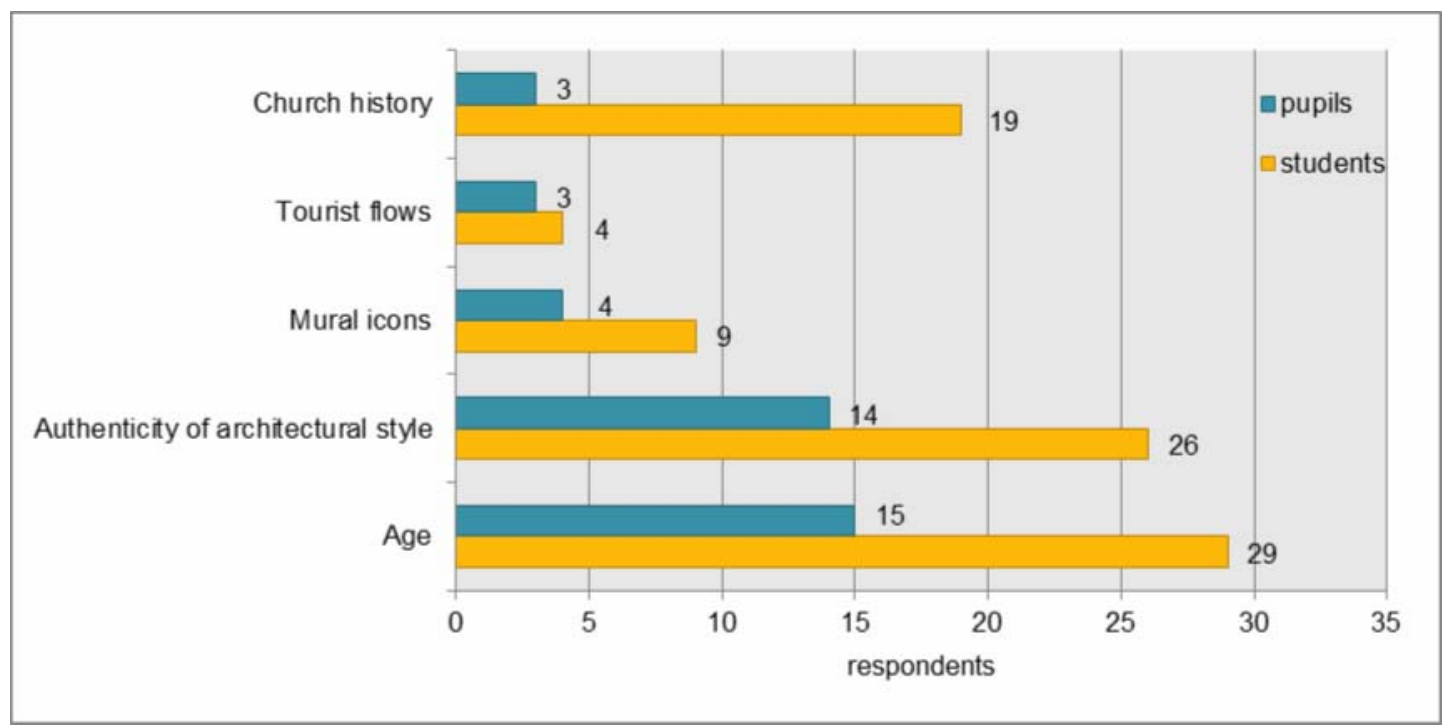

Fig. 8. Representations concerning the attributes giving monument value to old wooden or stone churches in general 


\section{SORIN-ALIN KOSINSZKI, MARIA ELIZA DULAMĂ, GABRIELA OSACI-COSTACHE, MARIA HOTEA}

At item number 10 - What are the attributes that give value to old wooden or stone monument churches in the Land of Maramureş? - almost $70 \%$ of pupils and around $88 \%$ of students answered that age is the factor that gave them value. In addition, almost all students responded that in addition to age, the authenticity of the architectural style was very important (Fig. 9). Although at the rest of the response variants of this item (see Fig. 9), pupils answered only in a small percentage, more than half of the students also gave importance to history (deeds, legends connected to that respective place of worship), but also to the mere fact of being wooden built (Fig. 9).

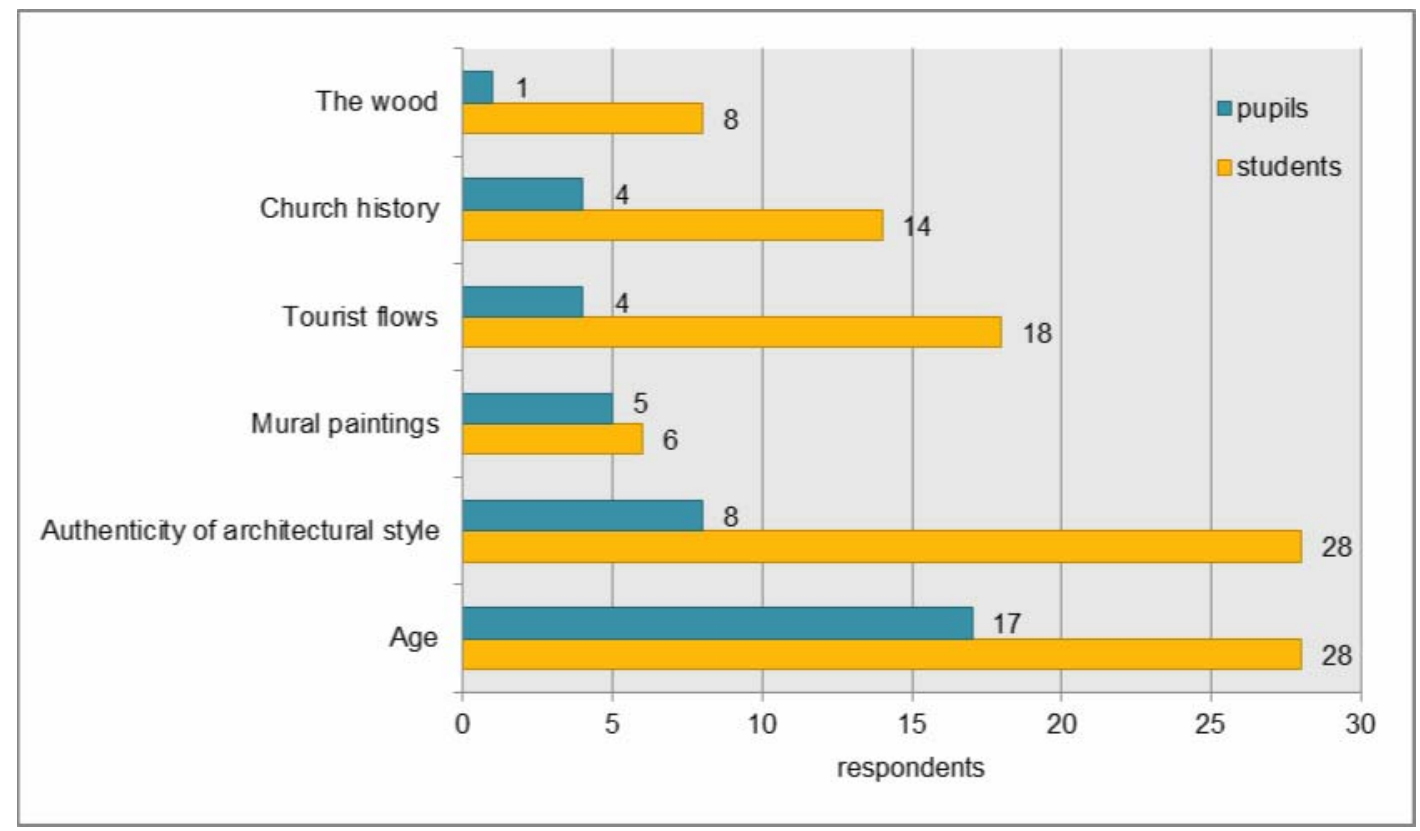

Fig. 9. Representations concerning the attributes giving monument value to old wooden or stone churches in the Land of Maramureş

At item number 11, the surveyed pupils and students were asked to explain the meaning of the term "UNESCO". The word is an acronym, in English, of the syntagm "United Nations Educational, Scientific, and Cultural Organization". Only five students answered correctly, and none of the pupils gave correct responses (Fig. 10). Four pupils did not answer the question, and the others gave answers such as: union that preserved; union that preserved the churches with value (4); union that came to preserve very old churches; The European Union that preserved the buildings; (2); union that preserved old buildings (4); union that preserved old monuments (3); community that preserved buildings (2); association that preserved old monuments; it is an association that preserved; association that preserved churches; association that preserved old buildings.

Six students did not answer the question, and the others provided diverse answers. Six students mentioned that it was an organization: Unique Nature Environmental, Social and Cultural Organization (1); The Organizing of United Nations for Education, Science and Culture (2); The Organization of United Nations for Education and Culture; The Organization 
of United Nations for Education (2); Organization in which the old monuments with a millenary history are found. Ten students mentioned that it was a heritage: world cultural heritage with natural and anthropic elements (6); world cultural heritage; world cultural heritage in which were enlisted the most important unique works of culture, religion, etc.; the UNESCO heritage represented the fact that all natural objectives were protected by the law; world patrimony that included and protected certain objectives for the value that these held. Other answers were: an entity with which certain goals were protected and promoted; National Environmental Union for cultural and educational purpose, it had a role to contribute to world peace and security through cooperation among nations and establish respect between them; a project that included the oldest monuments of wood and not only.

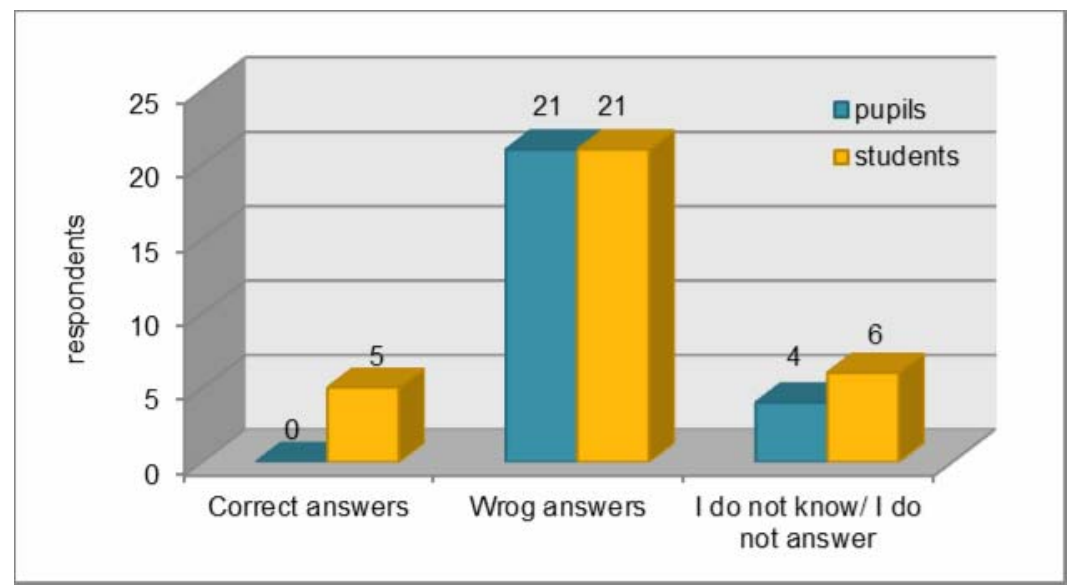

Fig. 10. What does UNESCO stand for?

At item number 12 - What is the corresponding name to UNESCO in Romanian? - only seven students answered correctly, while pupils did not provide any correct answers (Fig. 11). Several students explained with their own words at the previous item (11) what they should have answered actually at item 12, in a very exact manner. 18 students (56\%) and all the 25 pupils did not answer the question. The students gave answers such as: World cultural heritage (7); World heritage; World cultural heritage (natural elements + anthropic); ("UNESCO" heritage); United Nations Educational, Scientific and Cultural Organization (4). 


\section{SORIN-ALIN KOSINSZKI, MARIA ELIZA DULAMĂ, GABRIELA OSACI-COSTACHE, MARIA HOTEA}

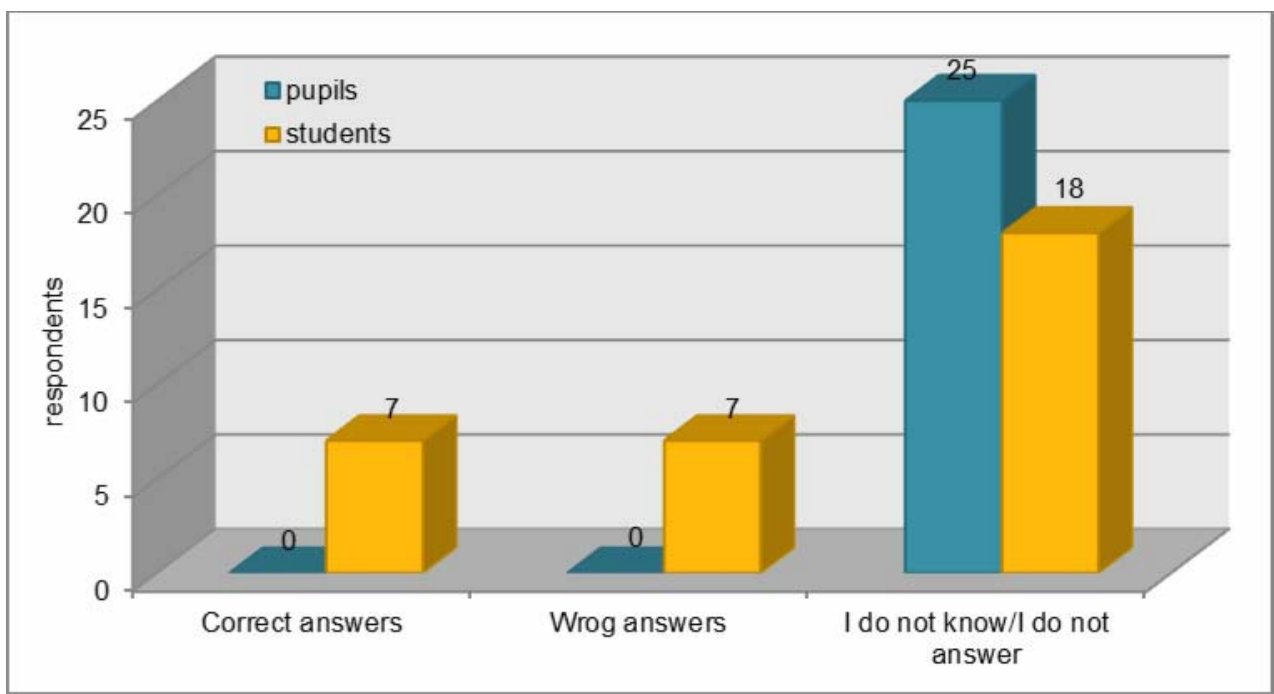

Fig. 11. Representations concerning the corresponding name of UNESCO in the Romanian language

At item number 13 - How many churches declared UNESCO World Heritage exist in the Land of Maramureş? - all the 25 pupils surveyed and 22 students $(69 \%)$ answered correctly, stating that there were 5 churches. At item number 14, the pupils and students surveyed were asked to identify the five old wooden churches in the Land of Maramures, declared UNESCO World Heritage, from seven response variants (Fig. 12). The pupils responded adequate at four of the five correct answers, nevertheless recording the most wrong answers (24) at the variant the wooden church "Mother Paraskeva", 1770, Deseşti locality, which, according to their perception and knowledge, is not part of the UNESCO World Heritage. The students identified, in a rather high percentage, of up to $96.9 \%$, the five old wooden UNESCO churches. The response the wooden church "Mother Paraskeva", 1604-1632, Poienile Izei locality, was considered correct by only six students, who knew that this church also belonged to the UNESCO World Heritage.

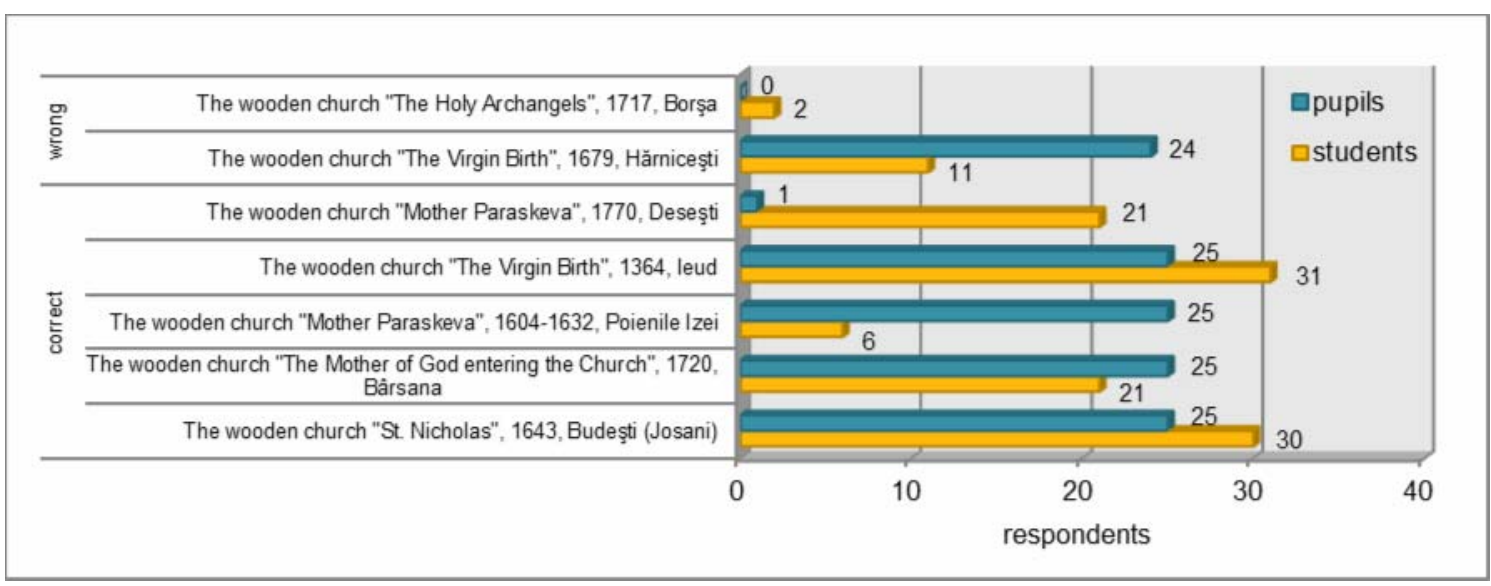

Fig. 12. Representations concerning the old wooden churches in the Land of Maramureş declared UNESCO World Heritage 
At item number 15, the surveyed pupils and students were asked to identify the attributes that led UNESCO to declare the churches in the Land of Maramureș as World Heritage component (Fig. 13). We considered as correct the answers concerning age, icons, authenticity of architectural style, and mural paintings. Pupils attributed value to age with 24 answers (96\%) and to the authenticity of the architectural style, with 25 answers $(100 \%)$. Pupils did not give importance to icons and mural paintings. Students attributed the most responses to age $(96.8 \%)$ and authenticity of the architectural style $(68.75 \%)$ and the least to icons and mural paintings (Fig. 13).

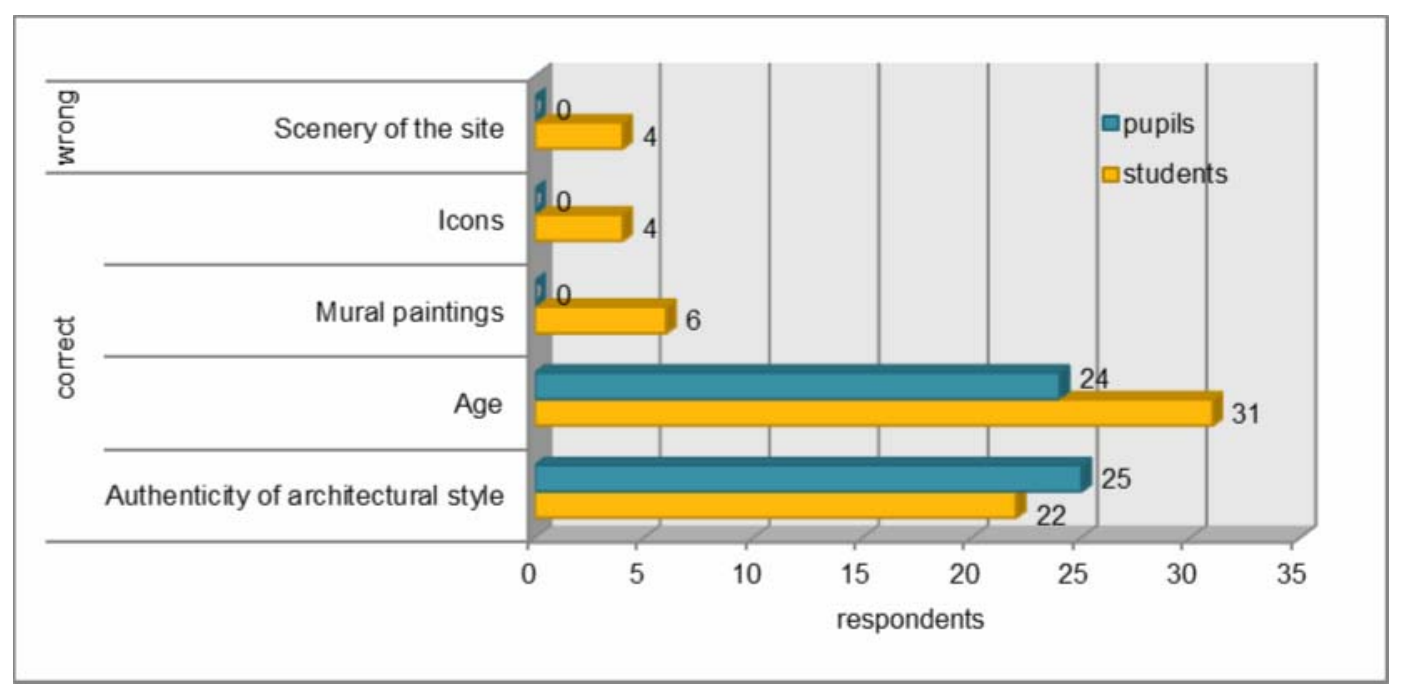

Fig. 13. Representations concerning the attributes that led UNESCO to declare the churches in the Land of Maramureş as World Heritage component

At item number 16 - What do you understand by tourism value? three pupils did not answer the question, and the others provided various answers. Some refered to tourists: the number of tourists that visited; more tourists; the multitude of tourists that made their presence felt at the wooden and historical monuments; that tourists came to admire the beauty of monuments; that they were visited by tourists, people from abroad that came to visit our monuments; that people wanted to find out about the past history. Other answers related to location: historical monuments and age; historical monument; a monument that was visited by many tourists; places that were very visited by tourists; age, architecture (3); it had very old monuments; visiting and admiring the old churches and monuments; that architecture and age attracted many tourists; a lot of old historical findings, religion; history, age; that the monument was very valuable; that they were very old; a place well arranged, old and very beautiful that was to the visitors' liking.

Five students did not answer the question, and the others gave answers such as the following: the value that a place or a building received, influenced by the tourism search; the value that a tourist attraction held; an attraction had tourist value when it had the capacity to generate tourists 


\section{SORIN-ALIN KOSINSZKI, MARIA ELIZA DULAMĂ, GABRIELA OSACI-COSTACHE, MARIA HOTEA}

flows; it had potential to attract tourists; how visited were the churches in the Land of Maramureş; how many tourists they attracted; age, history, authenticity, the set of a tourist attraction; the tourism value helped very much the economy of the country; an importance in tourism development; each tourist attraction had tourism value and was different as age; the way by which we attracted tourists, authenticity; importance of the objective for tourists and the potential that it had; tourism potential; the number of tourists that visited the monument gave tourism value; something that was worth visiting; the elements that gave attractiveness and attracted annual tourists flows; authenticity for the employment of a tourist attraction; authenticity of architectural style; the tourists flows; the number of tourists that visited the place, the specific works that existed, the fact that it was a brand a place had the highest value; something that was old and had tourists flows; the way in which a tourist attraction was valued; all the wooden churches had tourism value; the tourist attractions in the Land of Maramureş had tourism value due to: novelty and authenticity; the value that a tourist attraction deserved; age, architecture and history attracted tourists; architecture, keeping the traditions, the age of a monument, church, house, etc.

At item number 17, the surveyed pupils and students were asked to mention whether the old wooden/stone churches in the Land of Maramureş had tourism value apart from religious value. All the surveyed subjects responded with "yes".

At item number 18, the surveyed pupils and students were asked to mention what exactly determined a church/place of worship in the Land of Maramureş to have tourism value. One pupil and three students did not respond to the question. 21 pupils mentioned age and architecture; two, architecture, one pupil, age. Students mentioned: age (19), architecture (10), area, the location of the church (5), authenticity (4), the history of the church (4), authenticity of architectural style (3), the set (3), history (3), the wood from which it was built (3), it should have been on the UNESCO list (2), architectural style (2), value of the tourists flows (2), style (1), originality (1), mural paintings (1), history of the place (1), beauty (1), dimensions (1), the art of wood carving (1), the existing legends (1), connections to that place of worship (1).

At item number 19, the surveyed pupils and students were asked to mention what were the institutions or factors that, in their opinion, should have tended to preserving the old wooden churches and their tourism arrangement. All pupils mentioned that the Church should have implemented these actions of preserving and tourism arrangement, and a very small number of pupils responded that the local town halls and the villagers should have done that (Fig. 14). Most of the students considered that the Church, town halls and the Ministry of Tourism should have taken these steps, and the fewest responses were those aimed at the villagers and local tourism companies (rural guest houses). 
PUPILS' AND STUDENTS' PERCEPTIONS AND REPRESENTATIONS ...

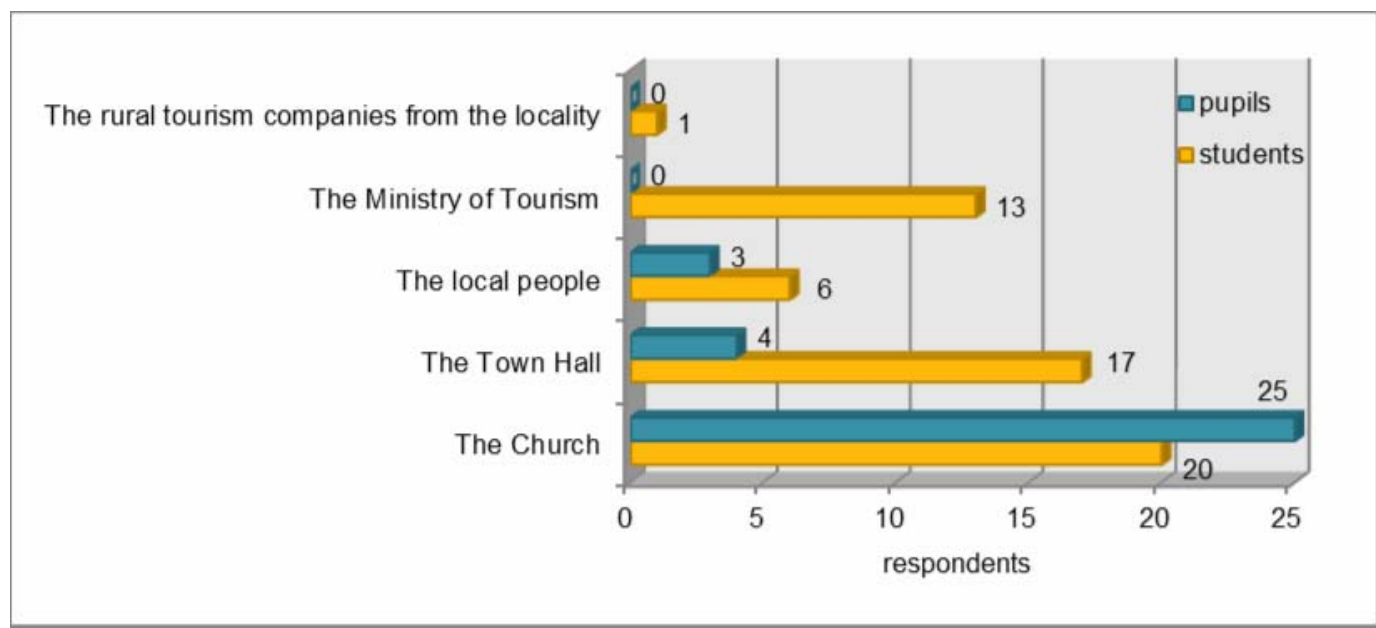

Fig. 14. Representations concerning the institutions/factors that should tend to preserving the old wooden churches and their tourism arrangement

At item number 20 (Fig. 15), most of the surveyed pupils established that their own contribution to the preservation of old wooden churches in the Land of Maramureş could consist of editing leaflets/brochures, writing projects on the subject, involving teachers in these efforts and organising school events, along with colleagues, to raise public awareness on the importance of preserving the old wooden churches. The students put the greatest emphasis on organizing student events to raise public awareness and editing leaflets/brochures, the other variants having less importance for them (Fig. 15).

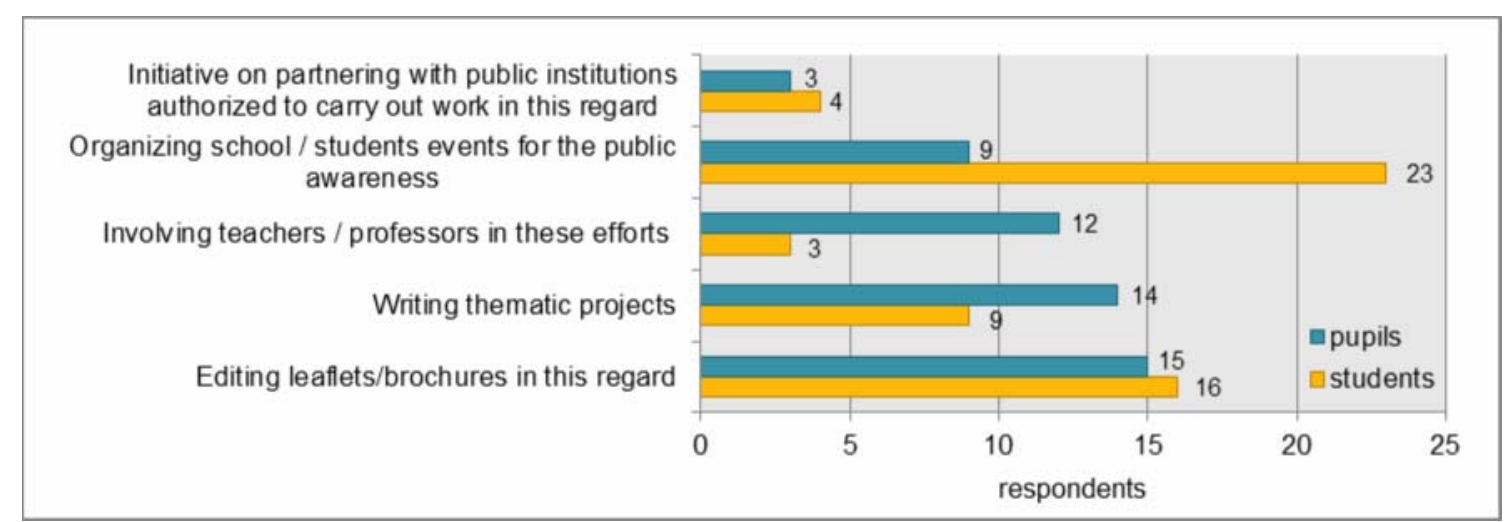

Fig. 15. Representations concerning the ways of personal involvement for the preservation of old wooden churches in the Land of Maramureş

At item number 21 (Fig. 16), most of the surveyed pupils established that their own contribution to the tourism promotion of the old wooden churches in the Land of Maramureş might have consisted of editing leaflets/brochures and writing projects. Apart from editing leaflets/brochures for tourism promotion, students scored many responses with editing thematic tourist maps with the location of the old wooden churches in the Land of Maramureş. 
SORIN-ALIN KOSINSZKI, MARIA ELIZA DULAMĂ, GABRIELA OSACI-COSTACHE, MARIA HOTEA

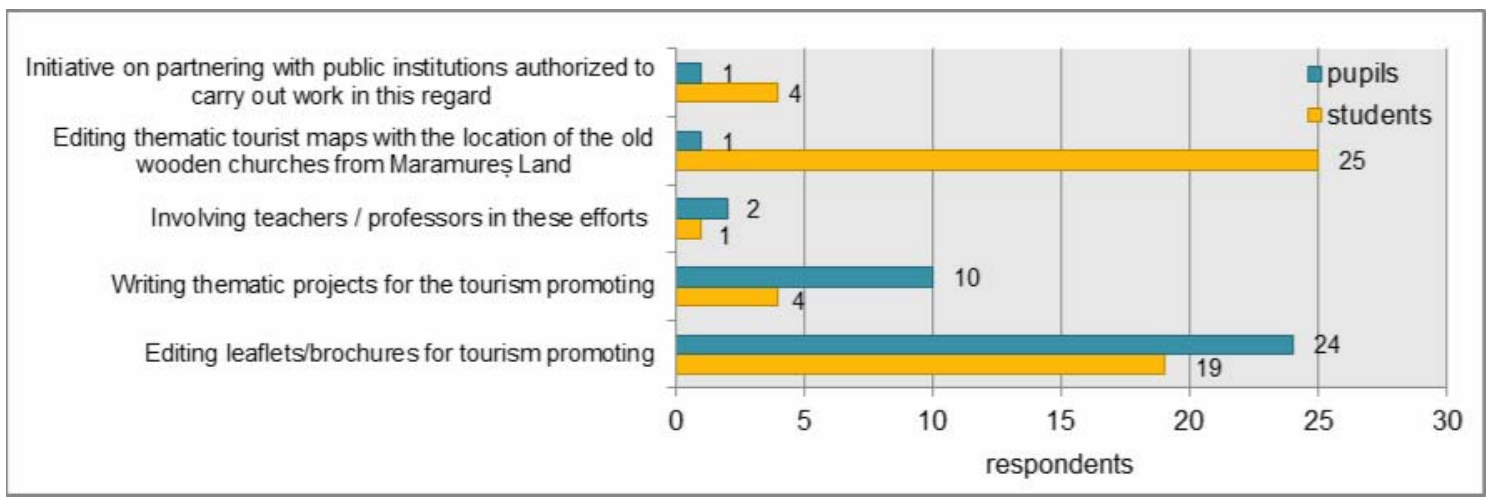

Fig. 16. Representations concerning the ways of personal involvement for the tourism promotion of old wooden churches in the Land of Maramureş

At item number 22, the surveyed pupils and students were asked to mention what old wooden churches in the Land of Maramureş they had visited. All pupils gave responses to this item, 20 of them having visited the old wooden church in their own locality, Bârsana, "The Mother of God Entering the Church", two pupils visited the Bârsana Monastery (monastic complex - new building), one pupil visited the old church from Ieud, one pupil visited the old churches in Bârsana, Ieud, Budeşti, one pupil visited the old churches in Bârsana, Sârbi, and Budeşti.

One student did not respond to the question. Six students visited one church, 13 students visited two churches, 9 students visited three churches, one student visited 6 churches, and one student visited 7 churches.

The students visited various churches: The old wooden church "The Mother of God entering the Church" in Bârsana (18), the Bârsana Monastery - new building (1), "The Virgin Birth" church in Ieud (21), Săpânţa - new building (4), The church of the Monastery in Moisei - "The Black Spring" (1), The old wooden church in Budeşti - "Saint Nicholas" (11), The church within the Border Police Headquarters - new building (2), The old wooden church "Mother Paraskeva" - Deseşti (7), "The Holy Archangels" - Sarasău (2), "The Holy Archangels" - Borşa (1), in Poienile Izei (2), Sighet (we do not know which church in Sighetu Marmaţiei they referred to), Bogdan Vodă (1), Rozavlea (1), Hărniceşti (2), Ocna Şugatag (1), Călineşti (1), Văleni (1), and in Sat Şugatag (1).

\section{DISCUSSION}

Through the first question, we sought to identify whether pupils or students knew correctly the name of the region where they lived, if they had gaps or made mistakes. Both pupils and students perceived correctly their ethnographical and geographical space and did not mistakenly associate the state of Maramureş with the Land of Maramureş, a fact that proved that they had some general knowledge of the geography and history of this region. 


\section{PUPILS' AND STUDENTS' PERCEPTIONS AND REPRESENTATIONS ...}

Through the second question, we sought to identify whether the respondents were familiar with the religions/confessions present in the Land of Maramureş. Pupils and students identified almost correctly the religions practised in the Land of Maramureş, fact which proved that they perceived in a correct manner the situation and that they accumulated knowledge although this was not being taught in school or faculty.

According to the final statistical results processed after the Census of Population and Housing $2011^{3}$, from the data available for Maramureş County, we extracted the corresponding values for the Land of Maramureş. In this region, with reference to our research which included, in addition to the rural areas, the following urban localities: Sighetu Marmaţiei, Borşa, Vişeu de Sus, Dragomireşti, and Săliştea de Sus, there were four religions/confessions: Orthodox, Catholic (with Greek-Catholics and RomanCatholics), Protestant, and Neoprotestant churches (Reformed, Baptists, Pentecostals, Unitarians, Adventists, Jehovah's Witnesses) ${ }^{1}$ and Judaism, the last ones especially in the town of Sighetu Marmaţiei.

At the item concerning the places of worship in the Land of Maramureş, we noticed the fact that pupils and students identified correctly, in a high number, the existence of wooden and stone churches as well, in this geographical and ethnographical space, and we explained these responses with the fact that most of them were Orthodox and that the churches, as buildings, were landscape highlights. The fact that they answered correctly that there were no mosques proved they were familiar with their appearance and the mosques had not been associated with this space. The fact that houses of prayer and synagogues did not stand out in the landscape as characteristic architecture, caused a large share of incorrect answers. In the Land of Maramureş, there was just one synagogue in Sighetu Marmaţiei, yet only 14 students noticed its existence. The answer seemed paradoxical (inconsistent) because at item number 2 only one student mentioned the existence of the Judaism in the Land of Maramureş. We therefore concluded that they did not know what Judaism was, yet they had a mental representation of the synagogue.

The item at which the subjects were asked to associate places of worship with religions/confessions was, apparently, easy to solve. We could not explain why 23 pupils (92\%) did not associate correctly Orthodoxy wooden churches and Catholicism - stone churches, yet associated the other religions correctly with their places of worship. The responses indicated that students had accurate representations relating to Orthodoxy wooden churches (as only one student associated wrongly). Mistakes on the other associations of places of worship with the corresponding confessions indicated that not all representations were accurate. This situation could be explained through the fact that the subjects had not studied at school (history or visual arts classes) or at faculty these issues in a way that ensured the sustainability of those representations.

3 Institutul Naţional de Statistică (2013), Recensământul populaţiei şi locuinţelor 2011. Retrieved from http://www.recensamantromania.ro/rezultate-2/. 


\section{SORIN-ALIN KOSINSZKI, MARIA ELIZA DULAMĂ, GABRIELA OSACI-COSTACHE, MARIA HOTEA}

The fact that 24 pupils (96\%) believed there were $16-20$ old churches/with monument value in the Land of Maramureş looked strange. We could explain this choice by the fact that they had influenced one another. The students' responses could be explained either by the fact that they did not have accurate representations of the correct number of old churches/with monument value in this geographical space or they did not appreciate all these churches to their proper value. It also seemed surprising that 25 pupils (100\%) answered correctly that in the Land of Maramureş there were 1-5 churches in the UNESCO world heritage, and out of the students only $50 \%$. The fact that 25 pupils considered that $11-15$ wooden built churches had monument value, when their real number was 32 , again indicated mutual influence. The students' responses again proved the absence of precise representations, especially that only two chose the correct answer.

The fact that all pupils and students believed that the wooden churches are the most valuable indicated to us the fact that they perceived them correctly as valuable, yet, in reality, the stone churches could be just as valuable. This item might induce, at a subliminal level, the representation that the wooden churches are more valuable than the stone built ones, a statement that cannot be generalized to other areas, but it is an element specific to the Land of Maramureş and also to north-western Transylvania.

Pupils' arguments on the value of churches were not strong enough. The fact that 23 pupils (92\%) said that these churches were valuable because they were old was not a strong argument because that would mean anything old was valuable and the older an object the more valuable it was. It was interesting the argument of a student that claimed that "the wooden churches are more valuable because wood is the material that lasts longer. The fact that it lasts gives them value".

According to literature, "in the Historical Maramureş the wooden churches impose themselves through monumentality fulfilling in some cases the role of true cathedrals, through dimensions, daring lines and proportions" (Man, 2007; p. 8), a fact emphasized by most students ("authenticity of architectural style"). One student highlighted their "originality", and another that "they present a characteristic architecture for this area and are characterized by age". Nevertheless, at item no. 9, 15 pupils and 29 students considered that age was the factor that gave these churches value, yet what impresseed, in the first place, was the original architectural style (14 pupils and 26 students) which gave certain specificity to this area. 19 students considered that history gave them value. Nevertheless, these churches did not have a different history from the other churches in the region, including the stone built ones, which were still present in a smaller number and were not as old. In addition, at item no. 10, 17 pupils and 28 students considered that age gave these churches value, yet what impressed was the original architectural style ( 8 pupils and 28 students) which gave certain specificity to this area. 18 students considered that history gave them value, nevertheless, these churches did 
not have a different history from the other churches in the region, and 14 considered these churches had value because thez were built of wood.

Regarding the name "UNESCO" and its meaning, we noticed that pupils did not have proper representations but they only inferred that it was an association, union or community dealing with the preservation of something (e.g. churches, buildings, old monuments). Some students mentioned that it was an organization or a union, while others referred to the cultural world heritage. Since only 5 students stated correctly the name in English and 7 in Romanian, we concluded that their representations were inaccurate.

We considered that all pupils answered correctly that 5 wooden churches in the Land of Maramureş were declared UNESCO World Heritage, although that response seemed strange compared to that given by the 22, of the 32 students, who answered correctly (20 students chose the answer 3 churches).

The pupils seemed to have influenced each other in the choice of the 5 churches in the Land of Maramureş declared UNESCO World Heritage, while the students' responses were statistically diverse, which demonstrated that they had inaccurate representations of these churches. The churches in the Land of Maramureş were declared UNESCO World Heritage in December 1999 COD 904, on the grounds of age, icons, authenticity of architectural style and mural paintings. These churches, "masterpieces of the wooden architecture of Maramureş, were introduced on the UNESCO World Heritage list, symbolically representing the hundreds of historical monuments in this category spread across all regions of Romania, being an outstanding Romanian contribution to the cultural heritage of humanity". "We noticed that pupils and students did not give any importance to icons and mural painting because they had not noticed or learned of their value, but were rather impressed by the architectural style and age of the church, and four students even by the scenery of the site.

Pupils made a confusion between the value of the objective itself (11) and its tourism value. Only eight pupils referred to tourists and one referred to the arrangement of the religious objective. In fact, we considered that the tourism value was a quality attributed to the tourist attractions (natural or anthropic), to attract visitor/tourist flows and to generate income from receipts for the tourism operators (travel agencies, hotels, guest houses, etc.), through the services of accommodation, meals, entertainment, tickets and souvenirs sales, etc. The surveyed students understood, in a large number, the significance of the tourism value concept, just due to attending the univeristy specialisation Geography of Tourism. Many of them addressed issues related to attractiveness and tourist flows; however, there were five students who did not respond to this item at all.

\footnotetext{
${ }^{4}$ Comisia Naţională a României pentru UNESCO, Retrieved from http://www.cnrunesco.ro/ro/patrimoniu.php.
} 


\section{SORIN-ALIN KOSINSZKI, MARIA ELIZA DULAMĂ, GABRIELA OSACI-COSTACHE, MARIA HOTEA}

At item no. 17, all the surveyed subjects claimed that the old wooden/stone built churches in the Land of Maramureş also possessed tourism value, apart from the obvious religious one, being aware of the fact that the ancestral values of civilization and Christian religious culture could contribute to regional sustainable development through religious tourism.

The fact that 21 pupils considered that a church/place of worship in the Land of Maramures had tourism value due to age and architecture proved once more the fact that they had problems in realising the value of these sites. Since no student highlighted the four characteristics that added value (i.e. age, icons, authenticity of architectural style, mural paintings) and only seven students identified two characteristics (age and architecture), it meant they had gaps of knowledge on this topic.

The fact that 25 pupils considered the Church should tend to the preservation of old wooden churches and their arrangement for tourism purposes proved that they did not perceive correctly the role of the Church or of the other institutions, especially that no pupil considered that the Ministry of Tourism would have had any responsibility for this matter. The fact that students considered responsible for the preservation of the old wooden churches and their arrangement for tourism along with the Church also the local municipalities and the Ministry of Tourism proved that they correctly perceived the role of each institution and public body. In Romania, according to the law no. 422 from the $18^{\text {th }}$ of July 2001 republished, concerning the preservation of historical monuments, art. 7 stated that "The Ministry of Culture is a specialised central public administration authority that develops strategies and specific rules for preserving historical monuments; it monitors and ensures their implementation". It is stated that "The authorities of the specialized central public administration, their subordinated relevant institutions and local authorities collaborate, and respond, as appropriate, for the preservation of historical monuments." (2001, pp. 2-3) ${ }^{5}$

The fact that 24 pupils and 19 students considered they could promote these churches by editing leaflets/brochures for tourism advertising meant that they considered that a good way of promotion and they thought of themselves as capable of doing it. The fact that ten pupils reckoned they could write projects for tourism advertising and that only four students chose this way of promotion seemed strange, yet we believe pupils thought of certain simple projects in which they applied the method of the projects as learning and evaluation method. Students were thinking of larger projects that could be implemented in practice, yet felt that they did not have the necessary skills to achieve them.

Concerning the visiting of churches, we considered natural the fact that 20 pupils visited the old wooden church "The Mother of God Entering the Church" in their own locality, Bârsana. We expected all of them to have

\footnotetext{
${ }^{5}$ Parlamentul României (2006). Legea nr. 422 din 18 iulie 2001, privind protejarea monumentelor istorice, republicată. Monitorul Oficial nr. 938/20 noiembrie 2006. Retrieved from http://www.cimec.ro/Monumente/pdf/Legea-422-2001-republicata-2006.pdf.
} 
PUPILS' AND STUDENTS' PERCEPTIONS AND REPRESENTATIONS ...

visited the Bârsana Monastery as well; nevertheless, only two pupils mentioned visiting it. It is a monastic complex built in 1995, so it is correct that they did not mention the visit.

Concerning the churches visited by students, the most answers were, in descending order, for "The Virgin Birth" church in Ieud (21), the old wooden church "The Mother of God Entering the Church" in Bârsana (18), the old wooden church "Saint Nicholas" - Budeşti (11), and the old wooden church "Mother Paraskeva" - Deseşti (7). Most visits were recorded at "The Virgin Birth" church in Ieud, because it was considered to be the oldest wooden church from Romania (year 1364) and thus it was presented to the students as a tourism brand as well. There was not a distinct typology in the frequency of visiting certain churches, based on grounds of the students' religion or place of origin (27 coming from the localities of the Land of Maramures and 5 from the town of Cavnic, therefore from the Land of Chioar). Students visited most of the tourist attractions in their local and regional horizon, especially during the field trips performed within their specialization - the Geography of Tourism.

Taking into account the high number of old wooden churches in the Land of Maramureş, and their value, the home locality of the students and their specialization, we would have expected them to have visited more of these churches. We considered that not all the students realised the value of these churches, neither had passion for these local, national, and universal values.

\section{CONCLUSIONS}

In this research, we reached several conclusions. First, pupils and students had better representation on the general aspects: the ethno-geographical area in which they lived, called the Land of Maramureş; the religions/confessions present in the Land of Maramureş, the existence of old wooden/stone built churches in this region; the value of the old wooden churches; the old wooden/stone built churches in the Land of Maramureş had religious as well as tourism value. They identified almost all religions in this area, although this was not being taught in school.

Unlike students, pupils, being Orthodox, had difficulties in associating places of worship with their corresponding confessions, which indicated that not all of them had precise, accurate representations. They did not have correct representations of what "UNESCO" meant, but rather felt it was an association, a union or a community dealing with the preservation of something (i.e. churches, buildings, old monuments), while students had more accurate and more complete representations.

The pupils and students make some wrong generalizations, for instance, when they consider that wooden churches are the most valuable, yet stone built churches can be just as valuable. 


\section{SORIN-ALIN KOSINSZKI, MARIA ELIZA DULAMĂ, GABRIELA OSACI-COSTACHE, MARIA HOTEA}

Pupils confused the religious value of the objective itself with its tourism value. They had difficulties in giving arguments because $92 \%$ of them said that wooden churches were valuable because they were old, and $84 \%$ believed that a church/place of worship in the Land of Maramureş had tourism value due to age and architecture. They proved that they did not realise the full value of these churches.

Pupils influenced each other in choosing some answers (for instance, in choosing the five old wooden churches in the Land of Maramureş declared UNESCO World Heritage), while students' answers were more statistically diverse.

Pupils did not perceive correctly the role of the Church, of the Ministry of Tourism, and of the town halls in the preservation of old wooden churches and their arrangement for tourism purposes, unlike students who perceived more correctly the role of each institution and public body.

Students also had knowledge gaps, thus no student had highlighted the four characteristics that added value (i.e. age, icons, authenticity of architectural style, and mural paintings) and only seven students identified two characteristics (age and architecture).

Pupils had formed many of the representations about religion, places of worship, including wooden churches, by living in this space, not by studying them at school (during history or visual arts classes), while students had formed richer and better representations, in addition, as a result of the courses lectured at the specialisation the Geography of Tourism.

Pupils formed richer representations about the wooden church in their town of residence and in the neighbouring villages that they visited, while the students had representations on many more churches in the Land of Maramureş, which they also visited.

From the data presentation and discussion, we concluded that, overall, the research hypothesis: pupils and students did not have very precise representations of the wooden churches in Maramureş and their employment as tourist attractions was confirmed.

We considered beneficial the application of this questionnaire to pupils and students and this research as well, because we assumed that by reading it, this would produce better awareness of the value of churches and lead to a more intense interest coming from pupils, students and teachers for knowing the old wooden churches and their value by studying the literature and by visiting them. 


\section{PUPILS' AND STUDENTS' PERCEPTIONS AND REPRESENTATIONS ...}

\section{References}

Comisia Naţională a României pentru UNESCO. Retrieved June 16, 2013, from http://www.cnr-unesco.ro/ro/patrimoniu.php.

Cristea, G., \& Dăncuş, M. (2000). Maramureş un muzeu viu în centrul Europei. Bucureşti: Editura Fundaţiei Culturale Române.

Institutul Naţional de Statistică (2013). Recensământul populaţiei şi locuinţelor 2011. Retrieved June 16, 2013, from http://www.recensamantromania.ro/rezultate-2/.

Ivanciuc, T. (2006). Ghidul turistic al Jării Maramureşului. Cluj-Napoca: Editura Limes.

Man, G. (2007). Biserici de lemn din Maramureş. Baia Mare: Editura PROEMA.

Parlamentul României (2006). Legea nr. 422 din 18 iulie 2001, privind protejarea monumentelor istorice, republicată. Monitorul Oficial nr. 938/20 noiembrie 2006. Retrieved June 16, 2013, from http://www.cimec.ro/Monumente/pdf/Legea-422-2001-republicata2006.pdf.

Roux, C., \& Du Preez, P. (2006). Clarifying Students' Perceptions of Different Belief Systems and Values: Prerequisite for Effective Education Praxis. SAJHE 20(3), 150-167, Unisa Press.

Terzidou, M., Stylidis, D., \& Szivas, M.E. (2008). Residents' Perception of Religious Tourism and Its Socio-Economic Impacts on the Island of Tinos. Tourism and Hospitality Planning \& Development, 5(2), 113-129.

\section{Appendix 1. The Questionnaire}

1. What do you understand by the Land of Maramureş?
a. The Maramureş County
b. The Historical Maramureş
c. The Country of Maramureş

2. What are the religions/confessions present in the Land of Maramureş?
a. Orthodoxy
b. Catholicism
c. Protestantism
d. Islam
e. Judaism
f. Taoism

3. What types of places of worship exist in the Land of Maramureş?
a. Pagodas
b. Wooden churches
c. Stone churches 
SORIN-ALIN KOSINSZKI, MARIA ELIZA DULAMĂ, GABRIELA OSACI-COSTACHE, MARIA HOTEA
d. Mosques
e. Houses of prayer
f. Synagogues

4. Associate places of worship from column B with religions/confessions from column A.
A.
B.
Orthodoxy
Pagodas
Catholicism
Synagogues
Protestantism
Stone churches
Islam
Houses of prayer
Judaism
Mosques
Taoism
Wooden churches

5. How many old churches / with monument value do you think there are in the Land of Maramureş?
a. 1-5;
b. 5-10;
c. 11-15;
d. 16-20;
e. 21-25;
f. Over 25;

Correct answer: f. (over 25)

6 . How many of these churches are built of stone?
a. 1-5;
b. 5-10;
c. 11-15;
d. 16-20;
e. 21-25;
f. Over 25;

Correct answer: b. (5-10)

7. How many of these churches are built of wood?
a. 1-5;
b. 5-10;
c. 11-15;
d. 16-20;
e. 21-25;
f. Over 25;

Correct answer: f. (over 25) 
8. Which old churches / with monument value in the Land of Maramureş do you think are more valuable: the wood or the stone built ones? Please motivated choice.

9. What are the attributes that give value for old wooden or stone monument churches in general?
a. Age
b. Authenticity of architectural style
c. Mural icons
d. Tourist flows
e. History

10. What are the attributes that give value for old wooden or stone monument churches in the Land of Maramureş?
a. Age
b. Authenticity of architectural style
c. Mural paintings
d. History
e. Wood
f. Scenery of the site

11. What does UNESCO stand for?

12. What is the corresponding name of UNESCO in Romanian?

13. How many churches declared UNESCO World Heritage are there in the Land of Maramureş?
a. 5
b. 3
c. 2

Correct answer: a. (5 churches)

14. Which are the churches in the Land of Maramureş declared UNESCO World Heritage?
a. The wooden church "Mother Paraskeva", 1770, Deseşti locality
b. The wooden church "St. Nicholas", 1643, Budeşti (Josani) locality
c. The wooden church "The Virgin Birth", 1679, Hărniceşti locality
d. The wooden church "The Mother of God Entering the Church", 1720, Bârsana locality
e. The wooden church "Mother Paraskeva", 1604-1632, Poienile Izei locality
f. The wooden church "The Virgin Birth", 1364, Ieud locality
g. The wooden church "The Holy Archangels", 1717, Borşa locality

Correct answers: a, b, d, e, f. Wrong answers: c, g

15. What are the attributes that led UNESCO to declare these churches in Maramureș Land as a World Heritage component?

a. Age 

MARIA HOTEA

b. Icons

c. Authenticity of architectural style

d. Mural paintings

e. Scenery of the site

Correct answers: $a, b, c, d$

16. What do you understand by "tourism value"?

17. Do you think that the old wooden/stone built churches in Maramureş Land have tourism value apart from the religious value?
a. Yes
b. No

18. What determines a church/place of worship in the Land of Maramures to have tourism value?

19. Who do you think should tend to preserving the old wooden churches and to their tourism arrangement?
a. The Church
b. The Town Hall
c. The Ministry of Tourism
d. The local people
e. The rural tourism companies in the locality (rural guest houses).

20. What could be my personal contribution to the preserving of old wooden churches in the Land of Maramureş?
a. Organizing school/students events for public awareness
b. Editing leaflets/brochures
c. Writing thematic projects
d. Initiative on partnering with public institutions authorized to carry out work
e. Involving teachers/professors in these efforts

21. What could be my personal contribution for the tourism promoting of old wooden churches in the Land of Maramureş?

a. Editing leaflets/brochures for promoting tourism

b. Editing thematic tourist maps with the location of the old wooden churches in the Land of Maramureş

c. Writing thematic projects for promoting tourism

d. Initiative on partnering with public institutions authorized to carry out work in this regard

e. Involving teachers/professors in these efforts

22. I visited the following old wooden churches in the Land of Maramureş: 